\title{
A Case Might Be Missed in the Emergency Department: Orf Disease
}

\author{
Acil Serviste Atlanabilecek Olgu: Orf Hastalı̆̆ı
}

Tarkan Küfeciler' ${ }^{1}$, Serbest Sancar², Semih Kulaç33, Egemen Kocabaş ${ }^{4}$

'Department of Emergency Medicine, Kırklareli State Hospital, Kırklareli, Turkey

2Department of Orthopedic and Trauma Surgery, Kırklareli State Hospital, Kırklareli, Turkey

${ }^{3}$ Clinic of Emergency Medicine, Taksim Training and Research Hospital, İstanbul, Turkey

${ }^{4}$ Department of Emergency, Aksaray State Hospital, Aksaray, Turkey

\section{ABSTRACT}

Introduction: Orf is a viral, zoonotic skin disorder and caused by DNA virus from Parapoxviridae group.

Case Report: It transmits to humans bu direct or indirect contact from infected animals, creates solitary-pustular lesions usually in hands, arms and face. In Muslim societies, the diease cause epidemics after Eid-al-Adha. Diagnosis is usually made by skin lesions, histopathological findings and history of contact. Develops as an occupational diease, orf diease can be recognised easily and resolves with syptomatic treatment.

Conclusion: In this essay we aim to present 8 cases of orf dieases which came to the emergency department after 2 weeks from Eid-al-Adha with nodular-bullous lesions and history of contact with meat.

\section{ÖZET}

Giriş: Viral zoonotik cilt hastalığı olan orf etkeni Parapoxvirus grubundan bir DNA virüsüdür.

Olgu Sunumu: Infekte hayvanlardan doğrudan veya dolaylı temasla insana bulaşarak, genelikle el, kol veya yüzde soliterpüstüler lezyonlar oluşturur. Müslüman ülkelerde hastalık kurban bayramları sonrasında epidemiler yapmaktadır. Tanı genellikle karakteristik deri lezyonları, histopatolojik bulgular ve temas öyküsü varlığı ile konur. Meslek hastalığı şeklinde ortaya çıkan orf hastalığı kolaylıkla tanınmakta ve semptomatik tedavi ile iyileşmektedir.

Sonuç: Biz bu yazımızda etle temas öyküsü olup kurban bayramından 2 hafta sonra acil servise nodüler-büllöz lezyonlar ile başvuran orf hastalığı olan 8 olguyu sunmayı amaçladık.

Keywords: Orf disease, contact with meat, symptomatic treatment

Received: 21.12.2012 Accepted: 26.04.2013

Anahtar Kelimeler: Orf hastalığı, etle temas, semptomatik tedavi Geliş Tarihi: 21.12.2012 Kabul Tarihi: 26.04.2013

\section{Giriş}

Ektima kontagiosum, kontagioz püstüler dermatit, infeksiyöz labial dermatit, koyun çiçeği, boğaz ağız, uyuz ağız, bulaşıc sığır ektiması ve kabuklanmış ağız olarak bilinen hastalık insanlarda görüldüğünde Orf olarak adlandırılmaktadır (1). Meslek hastalığı olarak çiftçilerde, çobanlarda, veteriner hekimlerde, kasaplarda ve et endüstri çalışanlarında görülür. Özellikle Müslüman ülkelerde kurban bayramları sonrasında epidemiler yapmaktadır (1, 2). Bu yazımızda etle temas öyküsü olup kurban bayramı sonrası acil servise nodüler-büllöz lezyonlar ile başvuran orf hastalığı olan 8 olgu sunuldu.

\section{Olgu Sunumları}

Olguların yaş ortalaması 44 (29-63) idi ve hepsi kurban bayramından 2 hafta sonra acil servise 1 haftalık periyot içerisinde başvurdular (Resim 1). 7 olgumuzda \%10 povidon iyot ile ıslak pansuman ve lokal mupirosin pomad ile taburcu edildi. Vakalarımızın iki tanesinde lezyon drene edildiği ve sekonder enfeksiyon gelişebileceği için oral amoksilin klavulanat 2000 mg/ gün (iki eşit dozda) başlandı. Tüm olgularımızın 15 gün sonraki kontrollerinde lezyonların gerilediği tespit edildi. Olgularımız

\section{Address for Correspondence/Yazışma Adresi:}

Tarkan Küfeciler, Department of Emergency Medicine, Kırklareli State Hospital, Kırklareli, Turkey.

Phone: +90 5333354242 E-mail: tarkankufeciler@mynet.com 


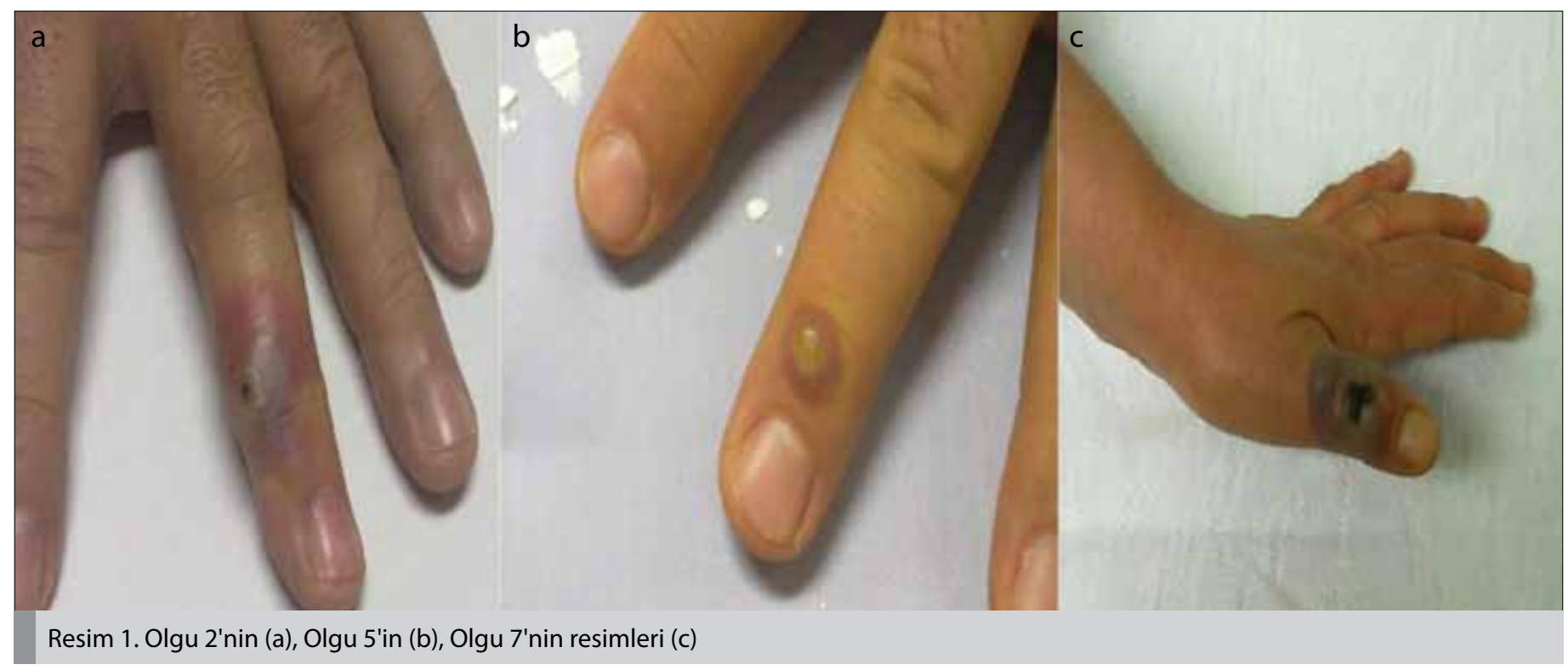

Tablo 1. Orf olgularının özellikleri

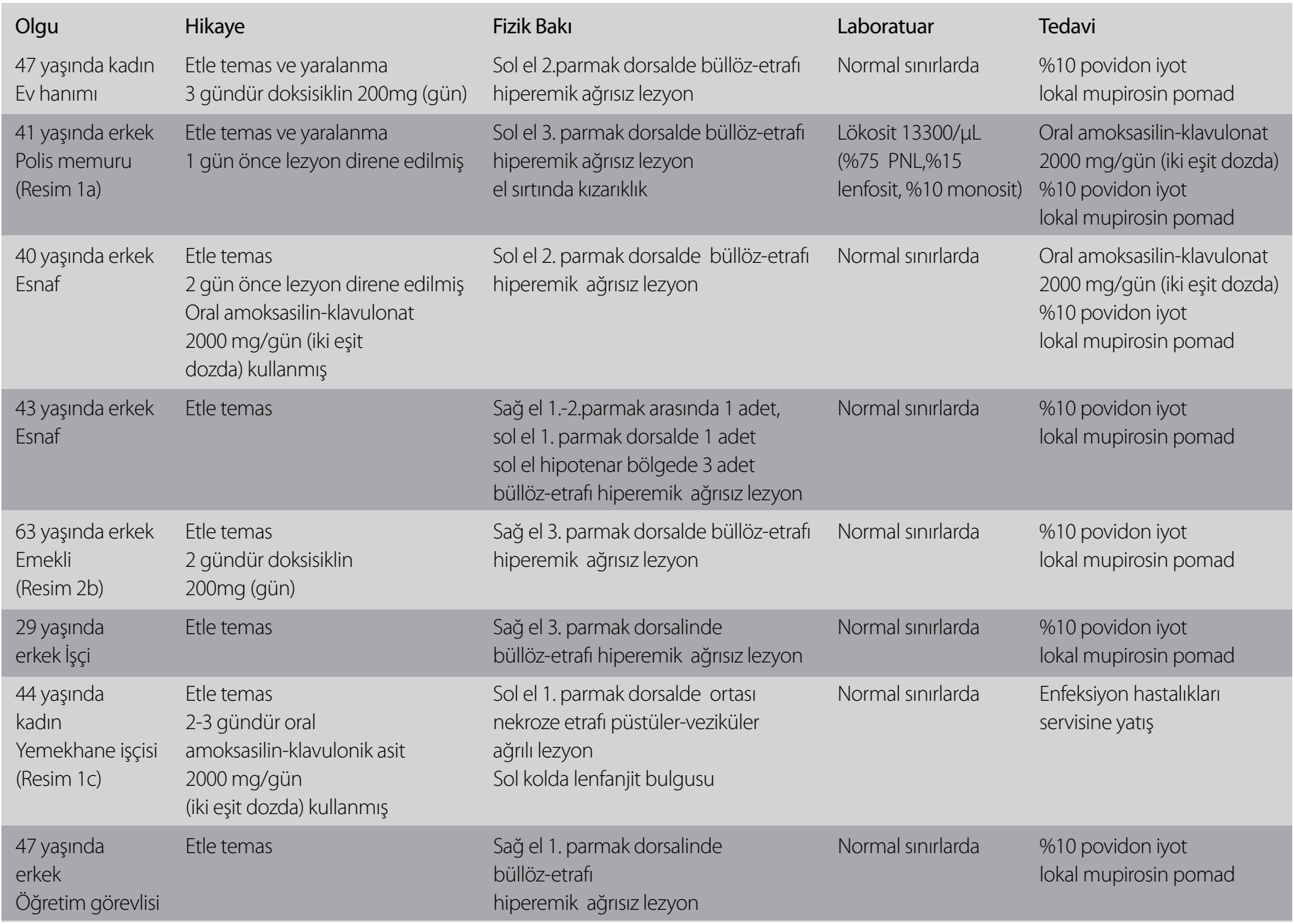

içinde sol el 1. parmak dorsalinde ortası nekroze etrafı püstülerveziküler ağrılı lezyonu ve sol kolunda lenfanjit bulguları olan hasta ise ileri tetkik ve tedavi için Enfeksiyon hastalıkları servisine yatışı yapıldı. Yatışı yapılan olgunun lezyonundan hazırlanan gram boyama, Giemsa smear preparatlarında patojen mikroorganizma görülmedi (Tablo 1). 


\section{Tartışma}

Epitelyotropik, DNA virüsleri grubuna ait Poxviridae ailesinin Parapoxvirus grubundadır. Etken virus hastalıklı hayvan ya da virus içeren materyal ile temas sonrası deri ve mukozalarda kendi kendini sınırlayan bir cilt enfeksiyonuna yol açmaktadır. Dış ortama oldukça dayanıklı olan virus, infekte materyal içinde uzun süre yaşayabilir. Özellikle bahar ve yaz aylarında insidansı artmaktadır. Kesin tanı; lezyondan alınan örnekte elektron mikroskobuyla virusun gösterilmesi, viral kültür, biyopsi materyalinin histopatolojik incelemesi, immünofluoresan antikor testleri ve diğer serolojik incelemeler ile konur (3-4).

Ayırıcı tanıda; deri şarbonu, herpetik paronişi abse, piyoderma gangrenozum, sütçü (Milker's) nodüller, Mycobacterium marinum, mantar enfeksiyonları veya piyojenik granülom akla gelmelidir (5). Ayrıcı tanıda şarbon hastalığı önemlidir. Şarbon genellikle ağrısız ama kaşıntılı bir papülle başlar. Ortasında siyah nekrotik krut, etrafında ödem ve ağrı ile devam eder. Lezyondan yapılan Gram boyamada lökositten fakir bir alanda Gram pozitif basiller görülür $(3,4)$. Bu enfeksiyona beraberinde subfebril ateş, halsizlik, lenfanjit ve bölgesel adenit eşlik edebilir (6). Bizim olgularımızda olduğu gibi çoğunlukla el ve parmaklarda soliter olarak ortaya çıkan lezyonlar nadir olarak yüz ve burun bölgesinde de görülebilir $(5,7)$. Orf lezyonları spontan olarak iyileştiğinden semptomatik tedavi dışında spesifik bir tedaviye gerek yoktur ve hastalığa karşı hayat boyu immünite gelişir. Lezyonun temiz tutulması ve bakımı yeterlidir. Lokal iyod kullanımının faydalı olduğu bildirilmiştir $(8,9)$. Sekonder enfeksiyon gelişirse antibiyotik kullanımı önerilir (5-9). Olgularımızdaki lezyonların parmaklarda yerleşmiş olması, karakteristik deri lezyonları, etle temas hikayesinin olması ve tedavilerde başarı literatürle uyumlu idi.

\section{Sonuç}

Orf hastalığında erken tanı konulamadığında gereksiz cerrahi müdahaleler ve tanısal incelemelere neden olabilir. Genellikle meslek hastalığı şeklinde ortaya çıkan orf hastalığı kolaylıkla tanınmakta ve semptomatik tedavi ile iyileşmesi beklenmektedir. Acil servislerde et ve et ürünleri ile temas hikayesi olan veziküler-püstüler lezyonları olan hastalarda orf hastalığını unutulmamalıdır. Orf hastalığından korunmada geçiş yollarının bilinmesi, el hijyenine dikkat edilmesi önemlidir.

Informed Consent: Written informed consent was obtained from patients who participated in this case.
Peer-review: Externally peer-reviewed.

Author Contributions: Concept - T.K.; Design - T.K., S.S.; Supervision - T.K., S.S.; Materials - T.K., S.S.; Data Collection and/or Processing - T.K.; Analysis and/or Interpretation - T.K., S.K.; Literature Review - T.K., E.K.; Writer - T.K.; Critical Review - T.K., S.S.

Conflict of Interest: The authors declared no conflict of interest.

Financial Disclosure: The authors declared that this study has received no financial support.

Hasta Onamı: Hastaların yazılı onamları alınmıştır.

Hakem Değerlendirmesi: Dış bağımsız.

Yazar Katkıları: Fikir - T.K.; Tasarım - T.K., S.S.; Denetleme - T.K., S.S.; Malzemeler - T.K., S.S.; Veri toplanması ve/veya işlemesi - T.K.; Analiz ve/veya yorum - T.K., S.K.; Literatür taraması - T.K., E.K.; Yazıyı yazan T.K.; Eleştirel İnceleme - T.K., S.S.

Çıkar Çatışması: Yazarlar çıkar çatışması bildirmemişlerdir.

Finansal Destek: Yazarlar bu çalışma için finansal destek almadıklarını beyan etmişlerdir.

\section{Kaynaklar}

1. Nourani H, Maleki M. Contagious Ecthyma: Case Report and Review. Pakistan Journal of Biological Sciences 2006; 9: 2543-5. [CrossRef]

2. Uzel M, Şaşmaz S, Bakarış S, Çetinus E, Bilgiç E, Karaoğuz A, et al. A viral infection of the hand commonly seen after the feast of sacrifice: human orf (orf of the hand). Epidemiol Infect 2005; 133: 653-7. [CrossRef]

3. Groves RW, Wilson-Jones E, MacDonald DM. Human orf and milkers' nodule: a clinicopathologic study. J Am Acad Dermatol 1991; 25: 706-11. [CrossRef]

4. Doğanay M, Eşel D. Bacillus anthracis ve diğer bacillus türleri. In: Topçu A, Söyletir G, Doğanay M. (eds). Enfeksiyon Hastalıkları ve Mikrobiyoloji. 3rd Ed. İstanbul: Nobel Tıp Kitabevleri; 2008. 2102-14.

5. Gurel MS, Ozardali I, Bitiren M. Facial orf. Turkiye Klinikleri J Med Sci 2003; 23: 412-5

6. Başkan EB, YılmazE, Doğruk S, Adım ŞB, Tokgöz N, Tunalı Ş. OrfVirus Infection in Pregnancy: a Case Report. Turkiye Klinikleri J Med Sci 2005; 25: 137-9

7. Gurel MS, Ozardali I, Bitiren M. Giant orf on the nose. Eur J Dermatol 2002; 12: 183-5.

8. Karabay O, Durmaz Y, Öztürk G. El Ülseri ve Ecthyma Contagiosum. Sakarya M J 2012; 2: 113-4. [CrossRef]

9. Turan E, Yurt N, Erdemir AT, Gürel MS. Fasiyal Orf. Turk J Dermatol 2012; 6: 58-60. 